\title{
Effect of using the additional field player on attack efficiency during 2017 Women's Handball World Championship
}

\author{
Tathyane Krahenbühl ${ }^{1} \bowtie$, Luis L. L. Pereira' ${ }^{1}$, Rafael P. Menezes ${ }^{2}$, Stephania M. F. Amazonas ${ }^{1}$, and Lucas Leonardo ${ }^{3}$ \\ ${ }^{1}$ School of Physical Education, University of Goiás, Goiânia, Brazil; ${ }^{2}$ School of Physical Education, University of São Paulo, Ribeirão \\ Preto, Brazil; and ${ }^{3}$ School of Physical Education, University of Campinas, Campinas, Brazil
}

\section{Abstract}

Background: Rule changes such as the use of the additional field player in the attack to replace the goalkeeper can significantly change the tactical strategies of the handball game. Objective: The aim of this study was to analyze the effectiveness of the use of the additional field player in offensive situations during the positional attack and counterattack suffered by the teams participating in the 2017 Women's Handball World Championship. Methods: The sample consisted of 15 matches in the knockout stage. In total, 1638 attack actions (positioned and counterattack) were identified and analyzed. For the exploratory analysis, we used descriptive statistics, obtaining the frequencies and respective percentages for each category of study variables for both situations: when the additional player was used and when not. Results: Our data showed that teams tend to use goalkeeper substitution by a field player to maintain numerical equality (54.9\%), followed by the use to obtain numerical offensive advantage (41.3\%). There were no differences in the throwing position (left wing, left back, center, pivot, right back and right wing) between situations with and without the additional field player. There was a significant increase in the number of errors when using the additional field player to gain numerical superiority in attack. In numerical equality and inferiority situations, no difference was found. The analyses also showed more counterattacks with goals and 9-m throws when using the additional field player. Conclusions: The use of the additional player did not bring advantages to the team, as more counterattacks were suffered.

Keywords: match analysis, seventh player, notational analysis

\section{Introduction}

Game analysis is an important procedure that provides athletes and teams with information, guides training and performance in competitions (Bilge, 2012; Daza et al., 2017) provides data on tactical organization, technical performance and helps to develop teaching methods by improving the quality of coaches interventions and influencing the strategic-tactical performance of the teams (Bilge, 2012; Karastergios et al., 2017; Prieto et al., 2015b).

Specifically, in handball, studies indicate that the effectiveness of group tactical actions is associated with a game played with greater depth of the playing space (Prieto et al., 2015b; Rogulj et al., 2011) and that fast counterattacks and the throw area are predictive factors of success in the attack (Gómez et al., 2014). Thus, it was observed that the players of the first offensive line have more throws of 9-m line, more assists, technical failures and loss the ball (Costa et al., 2017), while the wings and pivots score more points of fast counterattacks in 6-m line (Gómez et al., 2014).

While there are several game analysis studies that point to predictive performance factors in attack, these results predate the rule changes the Rio 2016 Olympic Games, allow teams to use seven players in the attack without the goalkeeper (International Handball Federation, 2016), in other words, any field player may replace the goalkeeper in attack actions, and it is not necessary to maintain a goalkeeper when the team is attacking.

In this context, it is known that this change in the rule interferes directly in the strategic-tactical structures of the game (Sevim \& Bilge, 2007), allowing new individual and group actions such as the organization of offensive and defensive systems. It is essential to analyze performance from the constraints and new situational possibilities (Taylor et al., 2008). Thus, the aim of this study is to analyze the effectiveness of the use of the additional field player in the attack and the counterattacks suffered in the 2017 Women's Handball World Championship.

\section{Methods}

\section{Sample and data collection}

The sample consisted of 15 matches in the knockout stage of the 2017 Women's Handball World Championship in Germany. This championship phase was chosen due to the need to win the match, which makes the teams take more risks in the strategies.

\footnotetext{
$\triangle$ Corresponding author: Tathyane Krahenbühl, e-mail tathy04n@gmail.com, ORCID ${ }^{\circledR}$ record https://orcid.org/0000-0001-6801-4861

Article history: Received October 21 2020, Accepted March 1 2021, Published March 262021

Copyright: (c) 2021 The Author(s). Published by Palacký University Olomouc. This is an open access article distributed under the terms of the Creative Commons Attribution License (https://creativecommons.org/licenses/by/4.0/), which permits unrestricted use, distribution, and reproduction in any medium, provided the original author and source are credited. This license does not cover any third-party material that may appear with permission in the article.
} 
One match was not included in the sample due to video failures (scoreboard with no time and scoring), rendering the analysis unfeasible. All attack actions were collected and analyzed, with a total of 1638 attack actions.

The games were analyzed using the official IHF images of public domain, and were performed by two independent observers, graduated in Physical Education and with more than five years of experience as teachers or handball coaches. Data collection took approximately two hours in each game.

\section{Independent variables}

Independent variables were selected for the study, such as positioning attack, counterattack, attack asymmetries and throwing place in both game situations, with and without the additional field player, which will be explained as follows.

The offensive situation is the time interval from the recovery of ball possession until a register action in which there is a situation of a total loss of possession, either by finalization or foul.

Counterattack is defined as the phase of the game in which the defending team switches over to the attack when they regain the ball possession, and comes to the finishing goal without organizing the opposing defense (Călin, 2010). In the same way, we considered in our analysis that the counterattack occurs in the following situations: a) the first movement to regain ball possession is the throw directly into the goal, without a pass, from where it was; b) when there is a goalkeeper's throw or a throw from the player with the ball to a player in displacement, who receives and throw, before the defense organization; c) fast attack, with more passing and collaboration between offensive players, however, the finalization of the goal still occurs with the unstructured defense.

For game situation analyses, we considered the relation between the number of attackers and defenders, disregarding the goalkeeper (when the goalkeeper is in the goal area). Thus, the following categories were established: a) numerical equality - both teams had the same number of field players, which is the same number of players on offense and defense not mentioning the goalkeeper; b) numerical inferiority - the attack had fewer players than the defense; c) numerical superiority - the attack had more players than the defense.

These asymmetrical situations were considered when there was a player's exclusion in the match, in other words, when a defensive player suffered exclusion and the attack had numerical superiority, but also in situations in which there was a substitution of the goalkeeper by an additional field player.

The position of the throw was considered. Therefore, we have seven possible throw positions, being left wing (LW), left back (LB), center (CE), pivot (PV), right back (RB), right wing (RW) and goalkeeper (GL).

\section{Dependent variable}

The efficiency of the attack was considered from the categories: a) goal (yes) - occurred when the ball passed the goal line completely, without any rule infraction by the attacker or by any team member before or during the throw; and b) goal (no) - goalkeeper's defense or loss of possession of a ball due to foul or error: occurred when the goal was defended by the goalkeeper and prevented the goal from being scored or when the attack lost the ball without the goal, due to technical error or irregular action by the attacking player.

\section{Statistical procedures}

For the exploratory analysis, we used descriptive statistics, obtaining the frequencies and the respective percentages. To associate the studied variables we used the chi-square test $\left(\chi^{2}\right)$, with the Monte Carlo correction when less than $20 \%$ of the cells had a value under 5 . The residual adjustments were calculated to identify which cells had significance in the statistical explanation from the relation between two variables.

We also analyzed the situations of the use of the additional player or not with: the percentage of use of the additional player by national teams, the percentage of throwing by position and the percentage by symmetry/asymmetry of the attack, and the comparison of the time of the attack using the Student $t$-test.

The value $p<.05$ was considered as significant. For the analysis, we used IBM SPSS (Version 20.0 for Windows; IBM, Armonk, NY, USA).

\section{Results}

Table 1 shows the total number of attacks analyzed in this study, separated by the teams that participated in the knockout stage of the Handball World Championship with their respective percentage of attacks with and without the use of the additional field player.

Figure 1 shows the percentages of throws per position, comparing descriptively their frequency with the use of the additional field player or not, in positional attack. There was no statistically significant difference between the throwing positions $\left(\chi^{2}(6)=3.85, p=.69\right)$, showing a tendency of the throws in the central position, in both situations.

The analysis of the effectiveness of the attacks in Table 2 showed that there is no difference in scoring goal when teams used the additional field player $\left(\chi^{2}(1)=3.01\right.$, $p=.08)$. This analysis did not take into account the situations of asymmetry of the game.

When analyzing the attacks asymmetries (inferiority, superiority and equality), no statistically significant difference was found (Table 3) in scoring goal when the additional field player was used in equality $\left(\chi^{2}(2)=0.61\right.$, $p=.43)$ or inferiority situations $\left(\chi^{2}(2)=0.06, p=.93\right)$. However, in superiority, the analyses showed that when the additional field player was used, the attack is less effective $\left(\chi^{2}(2)=4.34, p=.03\right)$. It is important to note that in this analysis, only positioned attacks were considered.

It is observed that the teams used the additional player mainly in situations to maintain the numerical equality (54.9\%), followed by the use to obtain numerical offensive advantage (41.3\%). 
Table 1 Team description of the total number of attacks analyzed in the study, and the percentage referring to the total number of attacks analyzed, with and without the use of the additional field player

\begin{tabular}{lccc}
\hline & $\begin{array}{c}\text { Did not use } \\
\text { the additional } \\
\text { field player }\end{array}$ & $\begin{array}{c}\text { Used } \\
\text { the additional } \\
\text { field player }\end{array}$ & Total \\
\hline Netherlands (3rd) & $196(13.7 \%)$ & $31(15.0 \%)$ & $227(13.85 \%)$ \\
Japan (16th) & $40(2.8 \%)$ & $21(10.2 \%)$ & $61(3.72 \%)$ \\
France (1st) & $185(12.9 \%)$ & $20(9.7 \%)$ & $205(12.51 \%)$ \\
Denmark (6th) & $77(5.4 \%)$ & $20(9.7 \%)$ & $97(5.92 \%)$ \\
Sweden (4th) & $200(14 \%)$ & $18(8.7 \%)$ & $218(13.3 \%)$ \\
Norway (2nd) & $136(9.5 \%)$ & $17(8.3 \%)$ & $153(9.43 \%)$ \\
Romania (10th) & $37(2.6 \%)$ & $14(6.8 \%)$ & $51(3.11 \%)$ \\
Spain (11th) & $43(3.0 \%)$ & $12(5.8 \%)$ & $55(3.35 \%)$ \\
Hungary (14th) & $42(2.9 \%)$ & $12(5.8 \%)$ & $54(3.29 \%)$ \\
Slovenia (15th) & $48(3.4 \%)$ & $11(5.3 \%)$ & $59(3.6 \%)$ \\
Montenegro (7th) & $104(7.3 \%)$ & $9(4.4 \%)$ & $103(6.28 \%)$ \\
Serbia (9th) & $51(3.6 \%)$ & $7(3.4 \%)$ & $58(3.54 \%)$ \\
Czechia (8th) & $104(7.3 \%)$ & $5(2.4 \%)$ & $109(6.65 \%)$ \\
Germany (12th) & $45(3.1 \%)$ & $5(2.4 \%)$ & $50(3.05 \%)$ \\
South Korea (13th) & $60(4.2 \%)$ & $4(1.9 \%)$ & $64(3.9 \%)$ \\
Russia (5th) & $64(4.5 \%)$ & $0(0 \%)$ & $64(3.9 \%)$ \\
Total & $1432(100 \%)$ & $206(100 \%)$ & $1638(100 \%)$ \\
\hline
\end{tabular}

Table 2 Attack effectiveness: Total number and percentages, comparing the situations in which the additional field player was used and not used (without considering the asymmetries of the attack)

\begin{tabular}{|c|c|c|c|}
\hline \multirow[b]{2}{*}{ Attack situation } & \multicolumn{2}{|c|}{ Goal } & \multirow[b]{2}{*}{ Total } \\
\hline & Yes & No & \\
\hline \multicolumn{4}{|c|}{ Did not use the additional field player } \\
\hline Count & 613 & 364 & 977 \\
\hline Relative (\%) & 62.7 & 37.3 & 100 \\
\hline \multicolumn{4}{|c|}{ Used the additional field player } \\
\hline Count & 69 & 57 & 126 \\
\hline Relative (\%) & 54.8 & 45.2 & 100 \\
\hline
\end{tabular}

Figure 1 Percentage of throws in game analysis by attack position, when using and not using additional field player in positional attack

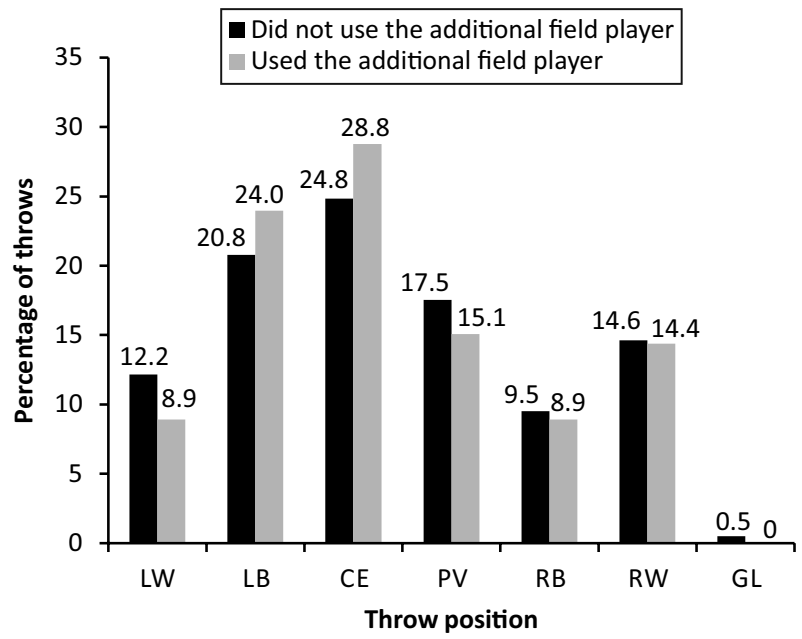

Note. $\mathrm{LW}=$ left wing; $\mathrm{LB}=$ left back; $\mathrm{CE}=$ center; $\mathrm{PV}=$ pivot, $\mathrm{RB}=$ right back; $\mathrm{RW}=$ right wing; $\mathrm{GL}=$ goalkeeper.
Significantly more goals were scored in counterattacks when using the additional field player $\left(\chi^{2}(1)=12.56\right.$, $p<.001$ ), see Table 4 .

Average attack time for attacks without the additional field player $(n=1169)$ was significantly lower than for attacks with the additional player $(n=140), 26.47 \pm 17.75$ $s$ vs. $38.26 \pm 15.41 s, p<.001$.

No statistically significant difference was found when comparing occurrences of $7-\mathrm{m}$ situations, $\left(\chi^{2}(2)=2.96\right.$, $p=.22$ ), see Table 5 .

Table 6 shows that when the additional field player was not used, there were more throws of $6 \mathrm{~m}$, while when the additional field player was used, there were more throws of $9 \mathrm{~m}\left(\chi^{2}(1)=7.22, p<.001\right)$ considering positional attacks.

\section{Discussion}

This study aimed to assess the effectiveness of the attack at the 2017 Women's Handball World Championship

Table 3 Attack effectiveness: Total number and percentages, comparing the situations in which the additional field player was used or not, considering the asymmetries of the attack

\begin{tabular}{|c|c|c|c|}
\hline \multirow[b]{2}{*}{ Attack situation } & \multicolumn{2}{|c|}{ Goal } & \multirow[b]{2}{*}{ Total } \\
\hline & Yes & No & \\
\hline \multicolumn{4}{|c|}{ Equality } \\
\hline \multicolumn{4}{|c|}{ Did not use the additional player } \\
\hline Count & 509 & 306 & 815 \\
\hline Relative (\%) & 62.5 & 37.5 & 100 \\
\hline \multicolumn{4}{|c|}{ Used the additional player } \\
\hline Count & 41 & 31 & 72 \\
\hline Relative (\%) & 44.1 & 26.9 & 100 \\
\hline \multicolumn{4}{|c|}{ Superiority } \\
\hline \multicolumn{4}{|c|}{ Did not use the additional player } \\
\hline Count & 85 & 41 & 126 \\
\hline Relative (\%) & 67.5 & 32.5 & 100 \\
\hline \multicolumn{4}{|c|}{ Used the additional player } \\
\hline Count & 27 & 26 & 53 \\
\hline Relative (\%) & 50.9 & 49.1 & 100 \\
\hline \multicolumn{4}{|c|}{ Inferiority } \\
\hline \multicolumn{4}{|c|}{ Did not use the additional player } \\
\hline Count & 19 & 17 & 36 \\
\hline Relative (\%) & 52.8 & 47.2 & 100 \\
\hline \multicolumn{4}{|c|}{ Used the additional player } \\
\hline Count & 1 & 1 & 2 \\
\hline Relative (\%) & 50.0 & 50.0 & 100 \\
\hline
\end{tabular}

Table 4 Suffered counterattack with a goal comparing the situations in which the attack used the additional field player or not

\begin{tabular}{lccc}
\hline & \multicolumn{2}{c}{$\begin{array}{c}\text { Goal scored in the } \\
\text { counterattack }\end{array}$} & \\
\cline { 2 - 3 } & No & Yes & Total \\
\hline Attack situation & 1332 & 90 & 1422 \\
\cline { 2 - 3 } Did not use de additional field player & 93.7 & 6.3 & 100 \\
$\quad$ Count & & & \\
$\quad$ Relative (\%) & 178 & 27 & 205 \\
Used the additional field player & 86.8 & 13.2 & 100 \\
$\quad$ Count & &
\end{tabular}


Table 5 Frequency of the occurrence of $7 \mathrm{~m}$ with and without goal converted in situations of use and not use of the additional field player

\begin{tabular}{lcccc}
\hline & \multicolumn{3}{c}{ Suffered 7 m } & \\
\cline { 2 - 4 } & $\begin{array}{c}\text { Yes, } \\
\text { with goal }\end{array}$ & $\begin{array}{c}\text { Yes, } \\
\text { no goal }\end{array}$ & No & Total \\
\hline Did not use the additional field player & & & \\
$\quad 76$ & 24 & 1332 & 1432 \\
$\quad$ Count & 5.3 & 1.7 & 93.0 & 100 \\
$\quad$ Relative (\%) & 15 & 6 & 185 & 206 \\
Used the additional field player & & & & \\
$\quad$ Count & 7.3 & 2.9 & 89.8 & 100 \\
$\quad$ Relative (\%) & & & &
\end{tabular}

Table 6 Frequency of throws according to the distance in relation to the use or not of the additional field player in positional attack

\begin{tabular}{lccr}
\hline & \multicolumn{2}{c}{ Throw line } & \\
\cline { 2 - 3 } Attack situation & $6 \mathrm{~m}$ & $9 \mathrm{~m}$ & Total \\
\hline Did not use the additional field player & & & \\
$\quad$ Count & 573 & 495 & 1068 \\
$\quad$ Relative (\%) & 53.7 & 46.3 & 100 \\
$\quad$ Used the additional field player & & & \\
$\quad$ Count & 54 & 77 & 131 \\
$\quad$ Relative (\%) & 41.2 & 58.8 & 100 \\
\hline
\end{tabular}

related to goalkeeper replacement by an additional field player, according to the possibility attributed by the recent rule change (International Handball Federation, 2016). This change allows teams to attack with up to seven players, increasing the frequency of asymmetric situations but allowing the risk of the goal being unprotected in handball matches.

The analysis showed that the throws occurred mainly from the central and right back position, with no difference whether the attack was using the additional field player or not, showing the tendency of the women teams in this championship to privilege the throws from these regions of the court. As in the results presented by Srhoj et al. (2001) in which they observed a greater frequency of throws from the central position, not having a significant influence on the results of the matches.

In addition, our data showed that teams often use the substitution of the goalkeeper by a field player to maintain numerical equality. The descriptive analysis showed that this feature was used although it did not increase offensive effectiveness, since whether or not to use the additional field player does not interfere with the attack effect. Garcia and Lorenzo (2010) suggest that the use of the "false goalkeeper", strategy to replace the goalkeeper with a court player before the new rule, is a strategy to be explored to balance the attacking team in cases of exclusion since the positional game in numerical equality can be a decisive aspect to define the winner or loser of the game (GutiérrezAguilar et al., 2010).

In our study, we observed that the teams used the additional field player to maintain equality and not allow the opposing team to increase the score in situations of numerical inferiority of the attack (Figure 1). Players' exclusions are critical moments and the instability arising from these situations of inequality changes the nature of cooperation and opposition of the teams and may affect the final outcome of the match (Ferreira, 2013). Teams that defend in superiority have obtained advantages in the result of the game (Matéfi, 2013), and having a player excluded allows disadvantages in the score for the team in numerical inferiority (Prieto et al., 2015a).

Furthermore, our findings showed that there were fewer goals scored with the use of the additional field player in superiority situations. Thus, it highlights the fact the use of the additional player was not effective for the attack in this championship. Musa et al. (2017) found that the use of an additional player in the attack is ineffective for offensive efficacy in accordance with the findings of our study, demonstrating that, in cases of exclusion, goalkeeper replacement is a strategy that does not result in differences in score in matches of elite handball. On the other hand, the use of the additional player in the attack may be a way to prevent the opposing team from advancing on the scoreboard during periods of a player's exclusion, since studies have shown that defense in numerical superiority has a decisive effect on the final results of the games (Matéfi, 2013; Prieto et al., 2015a).

However, a possible disadvantage of using the additional field player is the risk of leaving the goal unprotected when there is a danger of losing possession of the ball and suffering a counterattack. In this study, we have observed that when there is the use of the additional player to replace the goalkeeper, the frequency of the counterattack with a goal being scored are statistically significant. The counterattack is one of the most significant actions for success in handball matches (Srhoj et al., 2001), elite teams having a structured form of play, the success of the match is determined by counterattacks (Daza et al., 2017; Lozano Jarque \& Camerino Foguet, 2012; Saavedra et al., 2017), and leaving the goal unprotected shows a significant difference in our study.

Another point to be considered, shown by other studies (Gutiérrez-Aguilar et al., 2010; Trejo Silva \& Planas Anzano, 2018), is that winning teams are more effective in attack when compared to losing teams regardless of numerical superiority or inferiority, suggesting that winning the game depends on the combination of tactical, technical, physical and psychological aspects of teams and players, as well as the ability to adapt to the situation of numerical asymmetry.

Our study noted that when using the additional field player, there are more 9-m throws. This demonstrates that there is a tendency of these teams to use the finalization from the back line positions when using the additional field player. This tactical behavior is in agreement with other studies that show that there are more throws from the back-line positions (Hatzimanouil et al., 2017; Ohnjec et al., 2008). Another possible explanation may be related to the fact that the teams that defend in numerical inferiority increase the protection of the area (either by the change in the defensive system or by the rules of action of the defenders), providing larger spaces for throwing from long distances. 
The results showed that there was no association between the effectiveness of the attack and the use of an additional field player, in other words, the numerical superiority imposed by an additional attack player did not bring score benefits. In this context, there are no studies that can support the results of the present research due to the recent rule change. In addition, other studies on game analysis in handball do not consider the symmetries or asymmetries in the attack (Debanne, 2018; Oliveira et al., 2012; Vuleta et al., 2012), making it necessary to evaluate the effectiveness of offensive actions in a restrictive condition (GutiérrezAguilar et al., 2010; Sierra-Guzmán et al., 2015).

Some limitations of the study should be mentioned, such as not describing in detail which errors caused the attacks do not result in goals. Also, this is a study carried out with data from 2017, just one year after the official change of the goalkeeper substitution rule, which must be monitored for future evolutions in the way of playing with this new regulation.

\section{Conclusions}

It was shown that the additional player was used more often to maintain the numerical equality of the attack - when in a situation of exclusion - followed by situations of superiority (to have the extra player). However, there is a lower score in these situations of numerical superiority using the additional player.

There was a greater frequency of counter-attacks suffered, more time spent on the attack and a greater number of throws from $9 \mathrm{~m}$ when using the additional player.

Our data show that there was no clear advantage in the use of the additional field player, possibly due to the time proximity between the change the rule and the implementation of the championship analyzed in this study and the limited use in situations of sanctions, there is still a wide field for the development of offensive tactical options with this "additional" player. Therefore, over time, further studies are required to know whether the addition of the seventh player has really expanded the tactical offensive possibilities.

\section{Acknowledgments}

We thank the Laboratory of Studies and Research in Sports Pedagogy of the Federal University of Goias for academic support.

\section{Conflict of interest}

The authors report no conflict of interest.

\section{References}

Bilge, M. (2012). Game analysis of Olympic, World and European Championships in men's handball. Journal of Human Kinetics, 35(1), 109-118. https://doi. org/10.2478/v10078-012-0084-7

Călin, R. (2010). The analysis of the efficiency of using fast breaks in female handball during the World Championship in China, 2009. Ovidius University Annals, Series Physical Education \& Sport/Science, Movement \& Health, 10(2, Suppl.), 594-599. https://www.analefefs.ro/anale-fefs/2010/issue-2-supplement/peautori/44.pdf
Costa, G. C. T., Pedrosa, G., de Souza, N. P., Gemente, F. R. F., Freire, A. B., \& de Castro, H. O. (2017). Type of game practiced in handball according to the positions of the attackers: Analysis of the Women's World Handball Championship 2015. International Journal of Performance Analysis in Sport, 17(3), 360-373. https://doi.org/10.1080/24748668.2017.1345197

Daza, G., Andrés, A., \& Tarragó, R. (2017). Match statistics as predictors of team's performance in elite competitive handball. RICYDE. Revista Internacional de Ciencias del Deporte, 13(48), 149-161. https://doi.org/10.5232/ricyde2017.04805 Debanne, T. (2018). Effects of game location, quality of opposition and players' suspensions on performance in elite male handball. RICYDE. Revista Internacional de Ciencias del Deporte, 14(51), 71-83. https://doi.org/10.5232/ ricyde2018.05106

Ferreira, A. P. (2013). From game momentum to criticality of game situations. In U. McGarry, P. O'Donoghue, \& J. Sampaio (Eds.), Routledge handbook of sport performance analysis (pp. 270-282). Routlegde. https://doi. org/10.4324/9780203806913.ch22

Garcia, A., \& Lorenzo, J. (2010). Uso del "Portero Falso" en inferioridad numérica atacante: ¿Nueva Aportación Táctico-Estratégica? [About the use of "false goalkeeper" in attacking numerical inferiority: Is this a new tacticalestrategical contribution?]. E-balonmano.com: Journal of Sport Science, 6(1), 3-27. https://e-balonmano.com/ojs/index.php/revista/article/view/44

Gómez, M. A., Lago-Peñas, C., Viaño, J., \& Gonzáles-Garcia, I. (2014). Effects of game location, team quality and final outcome on game-related statistics in professional handball close games. Kinesiology, 46(2), 249-257. https://hrcak. srce.hr/file/194851

Gutiérrez-Aguilar, Ó., Fernández Romero, J. J., \& Borrás Rocher, F. (2010). Uso de la eficacia de las situaciones de juego en desigualdad numérica en balonmano como valor predictivo del resultado final del partido [Use of the effectiveness of the game situations in inequality numerical in handball as predictive value of the final score]. E-balonmano.com: Journal of Sport Science, 6(2), 67-77. https://e-balonmano.com/ojs/index.php/revista/article/view/41

Hatzimanouil, D., Giatsis, G., Kepesidou, M., Kanioglou, A., \& Loizos, N. (2017). Shot effectiveness by playing position with regard to goalkeeper's efficiency in team handball. Journal of Physical Education and Sport, 17(2), 656-662. https://doi.org/10.7752/ipes.2017.02098

International Handball Federation. (2016). Rules of the game. Edition of 1 July 2016. https://www.ihf.info/sites/default/files/2019-07/New-Rules $\% 20$ of $\% 20$ the $\% 20$ Game GB.pdf

Karastergios, A., Skandalis, V., Zapartidis, I., \& Hatzimanouil, D. (2017). Determination of technical actions that differentiate winning from losing teams in woman's handball. Journal of Physical Education and Sport, 17(3), 1966-1969. https://doi.org/10.7752/ipes.2017.03194

Lozano Jarque, D., \& Camerino Foguet, O. (2012). Eficàcia dels sistemes ofensius en handbol [Effectiveness of offensive systems in handball]. Apunts. Educació física $i$ esports, 2(108), 70-81. https://www.raco.cat/index.php/ApuntsEFE/article/ view/260934

Matéfi, E. (2013). Assessing defense strategies whilst in numerical superiority. In European Handball Federation, Master Coach Theses from the Hungarian National Course. Master Coaches' Theses - Part 2. http://cms.eurohandball.com/ PortalData/1/Resources/1 ehf main/3 download_pdf/HUN Theses_2.pdf

Musa, V., Modolo, F., Tsuji, G., Barreira, C., Morato, M., \& Menezes, R. (2017). Participação do goleiro-linha no handebol: Análise a partir do tempo de jogo, relação numérica, posto específico e match status [Participation of the linegoalkeeper in handball: Analysis from match time, numerical relationship, specific post and match status]. Revista Portuguesa de Ciências do Desporto, 17(S1A), 213-221. https://doi.org/10.5628/rpcd.17.s1a.213

Ohnjec, K., Vuleta, D., Milanović, D., \& Gruić, I. (2008). Performance indicators of teams at the 2003 World Handball Championship for Women in Croatia. Kinesiology, 40(1), 69-79. https://hrcak.srce.hr/24835

Oliveira, T., Gómez, M., \& Sampaio, J. (2012). Effects of game location, period, and quality of opposition in elite handball performances. Perceptual and Motor Skills, 114(3), 783-794. https://doi.org/10.2466/30.06.pms.114.3.783-794

Prieto, J., Gómez, M. Á., \& Sampaio, J. (2015a). Players' exclusions effects on elite handball teams' scoring performance during close games. International Journal of Performance Analysis in Sport, 15(3), 983-996. https://doi.org/10.10 80/24748668.2015.11868845

Prieto, J., Gómez, M. Á., \& Sampaio, J. (2015b). From a static to a dynamic perspective in handball match analysis: A systematic review. Open Sports Sciences Journal, 8, 25-34. https://doi.org/10.2174/1875399x01508010025

Rogulj, N., Vuleta, D., Milanović, D., Čavala, M., \& Foretić, N. (2011). The efficiency of elements of collective attack tactics in handball. Kinesiologia Slovenica, 17(1), 5-14. https://www.kinsi.si/en/archive/2011/210/ ucinkovitost-elementov-kolektivne-taktike-napada-v-rokometu

Saavedra, J. M., porgeirsson, S., Kristjánsdóttir, H., Chang, M., \& Halldórsson, K. (2017). Handball game-related statistics in men at Olympic Games (20042016): Differences and discriminatory power. Retos, 32, 260-263. https://doi. org $/ 10.47197 /$ retos.v0i32.56542

Sevim, Y., \& Bilge, M. (2007). The comparison of the last Olympic, World and European Men Handball Championships and the current developments in world handball. Research Yearbook, 13(1), 70-76.

Sierra-Guzmán, R., Sierra-Guzmán, S., Sánchez, F., \& Sánchez, M. (2015). Aanálisis de las situaciones tácticas ofensivas de la selección española masculina de balonmano en desigualdad numérica en los Campeonatos de Europa de Serbia 2012 y de Dinamarca 2014 [Analysis of the offensive tactical situations 
used by the Spanish men handball team in numerical inequality during the European Championships of Serbia 2012 and Denmark 2014]. E-balonmano. com: Journal of Sport Science, 11(1), 55-72. http://e-balonmano.com/ois/index. php/revista/article/view/168

Srhoj, V., Rogulj, N., \& Katić, R. (2001). Influence of the attack end conduction on match result in handball. Collegium Antropologicum, 25(2), 611-617. https:/ hrcak.srce.hr/index.php?show=clanak\&id clanak jezik=44648

Taylor, J., Mellalieu, S., James, N., \& Shearer, D. (2008). The influence of match location, quality of opposition, and match status on technical performance in professional association football. Journal of Sports Sciences, 26(9), 885-895. https://doi.org/10.1080/02640410701836887

Trejo Silva, A., \& Planas Anzano, A. (2018). Eficàcia ofensiva en situacions de desigualtat numèrica en l'handbol femení [Offensive efficacy in numerical inequality situations in female handball]. Apunts. Educació física $i$ esports, 1(131), 95-107. https://www.raco.cat/index.php/ApuntsEFE/article/view/332213

Vuleta, D., Sporiš, G., Vuleta, D., Jr., Purgar, B., Herceg, Z., \& Milanović, Z. (2012) Influence of attacking efficiency on the outcome of handball matches in the preliminary round of men's Olimpic Games 2008. Sports Science, 5(2), 7-12. https://sposci.com/PDFS/BR0502/SVEE/04\%20CL\%2001\%20DV.pdf 